\title{
Vascular compression of left renal vein: the nutcracker phenomenon
}

\author{
Priyank Yadav, ${ }^{1}$ Hira Lal, ${ }^{2}$ Pragati Verma, ${ }^{3}$ Chandan Mourya ${ }^{2}$
}

${ }^{1}$ Department of Urology and Renal Transplant, Sanjay Gandhi Postgraduate Institute of Medical Sciences, Lucknow, Uttar Pradesh, India

${ }^{2}$ Department of Radiodiagnosis, Sanjay Gandhi Postgraduate Institute of Medical Sciences, Lucknow, Uttar Pradesh, India ${ }^{3}$ Department of Radiology, Sanjay Gandhi Postgraduate Institute of Medical Sciences, Lucknow, Uttar Pradesh, India

\section{Correspondence to}

Dr Hira Lal,

hiralal2007@yahoo.co.in

Accepted 9 November 2016

\section{DESCRIPTION}

A 75-year-old woman presented to the outpatient clinic with symptoms of upper abdominal pain radiating to the back. On evaluation with contrastenhanced CT of the abdomen, she was found to have carcinoma of the body of pancreas. Incidentally, vascular compression of the left renal vein was seen between the superior mesenteric artery and the aorta (the nutcracker sign) (figure 1). In view of poor performance status, she underwent palliation with percutaneous splanchnic nerve radiofrequency ablation. Since she was asymptomatic for the vascular compression and serum creatinine was normal $(1.2 \mathrm{mg} / \mathrm{dL})$, she was observed for the same.

Nutcracker phenomenon is the vascular entrapment of the left renal vein (equivalent to nut) between the aorta and superior mesenteric artery (equivalent to hinged levers of a nutcracker) (figure 2). If symptomatic, it is known as nutcracker syndrome (NCS). ${ }^{1}$ The imaging equivalent of this phenomenon is the nutcracker sign. NCS was described as early as 1950 although the term nutcracker was introduced by Chait et $a l^{2}$ in1971.
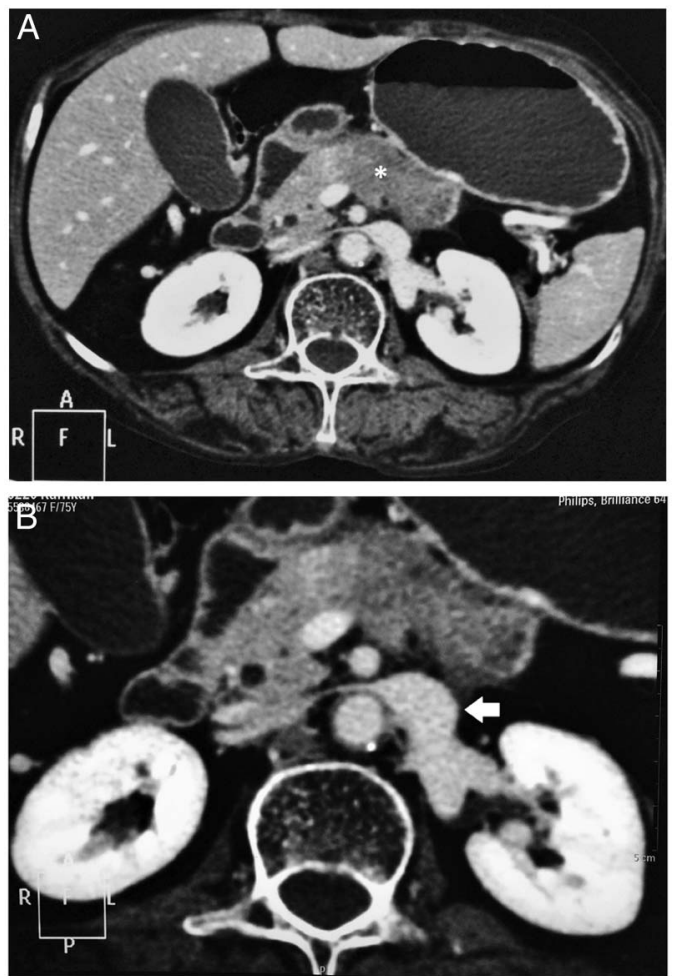

Figure 1 (A) Axial contrast-enhanced CT image showing mass lesion in the body of pancreas (asterisk) with dilated left renal vein, (B) magnified image showing compression of the left renal vein between the superior mesenteric artery and aorta with dilation of the proximal left renal vein (arrow).

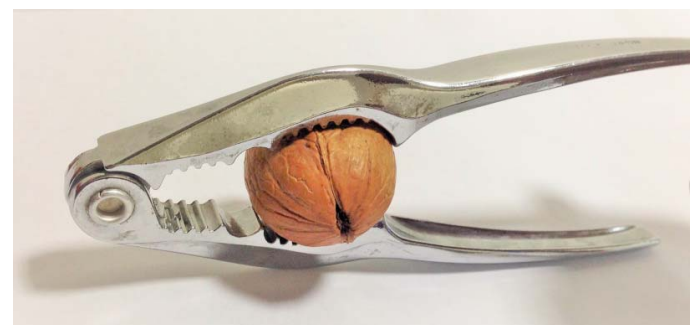

Figure 2 A nutcracker with two hinged metal levers and a nut in between.

It is more common in women. Clinical manifestations include left flank pain, haematuria, gonadal varices, hypertension and renal vein thrombosis. About one-third of the patients with vascular compression develop symptoms. ${ }^{1}$ If symptomatic, treatment is usually by endovascular methods. ${ }^{3}$

\section{Learning points}

- Nutcracker phenomenon refers to the compression of the left renal vein between the superior mesenteric artery and abdominal aorta.

- It is usually asymptomatic or may present with symptoms such as left flank pain, haematuria and hypertension, and hence it is called nutcracker syndrome.

- Symptomatic patients can be successfully managed with endovascular methods in majority of the cases.

Contributors $\mathrm{HL}$ conceived the manuscript. CM and PV performed the data acquisition. PY prepared the manuscript. HL edited the manuscript. All authors reviewed the final manuscript and approved it for submission.

Competing interests None declared.

Patient consent Obtained.

Provenance and peer review Not commissioned; externally peer reviewed.

\section{REFERENCES}

1 Yun SJ, Lee JM, Nam DH, et al. Discriminating renal nutcracker syndrome from asymptomatic nutcracker phenomenon using multidetector computed tomography. Abdom Radiol (NY) 2016;41:1580-8.

2 Chait A, Matasar KW, Fabian CE, et al. Vascular impressions on the ureters. Am J Roentgenol Radium Ther Nucl Med 1971;111:729-49.

3 Rudloff U, Holmes RJ, Prem JT, et al. Mesoaortic compression of the left renal vein (nutcracker syndrome): case reports and review of the literature. Ann Vasc Surg 2006;20:120-9. 
Copyright 2016 BMJ Publishing Group. All rights reserved. For permission to reuse any of this content visit http://group.bmj.com/group/rights-licensing/permissions.

BMJ Case Report Fellows may re-use this article for personal use and teaching without any further permission.

Become a Fellow of BMJ Case Reports today and you can:

- Submit as many cases as you like

- Enjoy fast sympathetic peer review and rapid publication of accepted articles

- Access all the published articles

- Re-use any of the published material for personal use and teaching without further permission

For information on Institutional Fellowships contact consortiasales@bmjgroup.com

Visit casereports.bmj.com for more articles like this and to become a Fellow 